\title{
DIVISION OF THE GEOLOGICAL SECTION INTO HOMOGENEOUS DRILLABILITY INTERVALS BASED ON THE RESULTS OF MODELING THE PROPERTIES OF ROCKS IN THE DRILLING PROCESS
}

\author{
Piriverdiyev I.A. \\ Institute of Oil and Gas of Azerbaijan National Academy of Sciences \\ 9, F.Amirov str., Baku, AZ1000, Azerbaijan: igorbaku@yandex.ru
}

\begin{abstract}
Summary. Improving the efficiency and quality of well drilling largely depends on improving the quality of information received. The quality of decisions made during drilling also substantially depends on the quality of information. Widely used in recent years in world practice, mud logging in the process of drilling allows us to solve a number of problems in the drilling process, when in-

Keywords: complex information, geological section, rock, bit, complications, classification, decision-making, uncertainty, fuzzy logic formation about the section of the well being drilled is missing or is available in a limited amount. The application of the results of the complex of geological, geophysical and technological research allows us to study more deeply the section and thereby improve the quality of decisions.

The article discusses ways to improve the quality of information and obtain more extensive information about the drilled rock, which allows us to divide the section into homogeneous intervals. For this purpose, an approach known from fuzzy logic was applied to find the appropriate criterion for each of the indicators under consideration, and then their average harmonic value was calculated. The relationship between the mean harmonic value and the depth serves to define the boundaries between the intervals. The above algorithm was used for calculations for four wells in the Bahar field, and the results were clearly demonstrated using figures.

(C) 2020 Earth Science Division, Azerbaijan National Academy of Sciences. All rights reserved.
\end{abstract}

\section{Introduction}

The efficiency and quality of well drilling largely depends on the quality of the information received. The quality of decisions made during the drilling process also substantially depends on the quality of information. The low quality of the information received is one of the reasons for making erroneous decisions, which in turn leads to complications, accidents and in general to a decrease in the technical and economic indicators of well drilling. The aforementioned as well as the experience of drilling wells and numerous studies indicate the need to use appropriate methods of data processing and information analysis.

In recent years a large number of studies have accumulated on the process of interaction of a rockcutting tool with a rock, in which methods and tools for determining the physical-mechanical properties and abrasiveness of rocks are proposed. These include experimental studies, studies based on the analysis of geological and geophysical information, as well as based on classification methods. In gen- eral, an analysis of the work performed shows that it is now possible to increase the level of decisions made by using complex geological, geophysical and technological information which forms the basis of technological decisions. Information of this nature can be obtained in various ways but to obtain and use such information it is also necessary to use modern methods of data processing and information analysis. In this regard the proposed article is devoted to improving the efficiency of using the information obtained in the process of drilling wells in order to improve the quality of decisions.

2. The value of integrated information in modeling the properties of rocks and the process of drilling wells

Gained in recent years in world practice widespread use of mud logging in the drilling process allows us to solve a number of problems in the drilling process, when information about the section of the well being drilled is missing or is available in a limited amount. The application of the results of mud logging in combination with well logging al- 
lows a deeper study of the section and thereby improves the quality of decisions.

As noted in (Ракитин, 2015), well loggingdrilling (LWD) is the most interesting and rapidly developing area in the field of logging. When drilling onshore as a rule there are quite a lot of exploratory wells, which allow you to build a fairly reliable geological model. Production drilling at old fields is mainly of a clarifying nature. When drilling at sea and developing new fields with horizontal shafts, the role of LWD and solving geo-navigation problems is much more complicated. In addition, LWD is increasingly used in exploratory wells. This is due to the following circumstances:

1) obtaining technological data directly from the bottom provides an opportunity not only to reduce accident rate while drilling in new areas but also suggests the possibility of developing new directions of LWD;

2) the use of gamma-ray logging (GL) and electrolytic logging (EL) data during drilling allows not only to determine the most accurate coring intervals but also to develop a technique for repeated EL measurements at a higher level;

3 ) the most reliable data on flow rates can be obtained during tests from the offshoot with horizontal ending in promising collectors.

The limiting factor in the use of LWD on shelf exploratory wells is the high cost of using foreign equipment. LWD is most widely used in the construction of production wells. The article (Делия, Ракитин, 2014) presents prediction of development tendencies of mud logging and well logging on experience of well drilling at the example of "LUKOIL-Nizhnevolzhskneft" LLC in the north of the Caspian Sea.

\section{Methods of investigation}

When analyzing geological and technological information on well drilling in particular and data related to measurements in general, one has to deal with errors, uncertainty and unstable correlations between the studied parameters. Such difficulties are inherent in technical, technological, geological and geophysical studies due to the difficulties associated with the creation and use of more accurate instruments for measuring drilling performance, formation characteristics, especially with a complex geological structure, operational parameters, etc. It becomes very difficult to conduct a comparative analysis between values of the same parameter measured in different ways.

For instance, when analyzing the operation of the bits it is advisable to divide the section into homogeneous intervals and consider the patterns of changes in drilling performance within them. For these purposes various classification methods have been proposed. One of the simple methods that allows this operation to be performed is the method of D.A. Rodionov, known from geology, which was applied in drilling (Efendiyev et al., 1991). According to this method the massif over the entire depth is first assumed to be homogeneous, and then the Rodionov criterion for each interval is calculated according to the expression (1) proposed by the author:

$$
V\left(r_{0}^{2}\right)=\frac{n-1}{n(n-K) K} \sum_{j=1}^{m} \frac{\left[(n-K) \sum_{j=1}^{k} \chi_{i j}-K \sum_{i=k+1}^{n} \chi_{i j}\right]^{2}}{\sum_{i=1}^{n} \chi_{i j}^{2}-\frac{1}{n}\left(\sum_{i=1}^{n} \chi_{i j}\right)^{2}}
$$

According to the analysis of (Родионов, 1968), the values of the Rodionov criterion are distributed obeying the law of $\chi^{2}$ Pearson. Therefore, the program provides a comparison of each calculated value with a table one for a given level of significance within each interval. The intervals corresponding to the excess of the calculated value of the criterion over the tabular value $\chi^{2}$ of Pearson are the boundary between two homogeneous packs that are heterogeneous with each other.

Many theoretical models have been developed to predict or correlate specific physical properties of porous rock. Most theoretical models are built on simplified physical concepts: what are the properties of an ideal porous media. However, in comparison with real rocks, these models are always oversimplified. Most of these models are capable of "forward modeling" or predicting rock properties with one or more arbitrary parameters. However, as is typical in earth science, models cannot be inverted from measurements to predict uniquely real rock and pore-fluid properties. Many efforts have been made and will continue to be made to build porous rock models but progress is very limited. Some of the most fundamental questions are still unanswered.

(Taylor et al., 2015) modeled reservoir quality evolution using the forward diagenetic model Touchstone, which simulates porosity loss due to compaction and quartz cementation. Quantitative petrographic analyses and burial history data were used to calibrate Touchstone model parameters. The results were applied to deeper prospects for pre-drill prediction of porosity and permeability. There was also an attempt to model the dynamic moduli of porous rocks saturated with viscous fluid at seismic frequencies on core scale based on the strain-stress method, aiming to provide a complement to real core measurements in lab (Wang et al., 2016). First the authors build 2D geometrical models containing the pore structure information of porous rocks based on the digital images (such as thin section, SEM, CT, 
etc.) of real rocks. Then they assume that the rock frames are linearly elastic and use the standard Maxwell's spring-dash pot model to describe the viscoelastic properties of pore fluids. Boundary conditions are set according to the stress-strain method; and the displacement field is calculated using the finite element method (FEM). They numerically test the effects of pore structure on the viscoelastic properties of saturated rocks. The preliminary results indicate that the pore structure parameters, such as porosity, aspect ratio (AR), and pore size affect the rock frame stiffness and results in different viscoelastic behavior of the saturated rocks.

The paper (Wawrzyniak-Guz, 2019) presents an application of rock physics templates constructed with the use of the granular effective medium theory and the shale model to estimate the elastic properties of the Silurian and Ordovician shale formations from the Baltic Basic, Poland. The author uses available logging data from three nearby wells and their petrophysical interpretation to distinguish various lithological types and to determine average matrix mineral composition of each lithology group, essential in further rock physics modelling. Anisotropy estimation and investigation of the relation between various petrophysical parameters precede the rock physics modelling. The paper includes also the proposition of the final rock physics template constructed for the Silurian and the Ordovician formation from the Baltic Basin that can contribute to a better understanding of the elastic properties of the lower Paleozoic shale plays in Poland.

To date fuzzy logic has also been successfully applied in the assessment and use of reservoir characteristics. Even in the past researchers in the field of natural sciences noticed that many, at first glance, random events are accompanied by certain laws. Later these regularities, or distributions, were closely approximated by continuous curves called "normal distribution curves of errors" and assigned to the laws of probability (Brown et al., 2000; Cuddy, Glover, 2002). In general analysis shows that the solution of problems of modeling technological processes is significantly hampered by the presence of uncertainty associated with the use of random and fuzzy quantities. Random variables convey the fact that the studied quantities can take different values with different probabilities. Fuzzy quantities convey approximation in determining the values of these quantities themselves. In addition, fuzzy values may be preferable in case of insufficient statistical data and related information necessary for more reliable estimates. Such estimates of the mechanical properties of rocks can be made according to their physical properties, estimated using well logging using probabilistic-statistical methods and the theory of fuzzy sets. The study of the considered dependencies made it possible to develop a reasonable design scheme for assessing the characteristics of the geological section.

\section{Information analysis and results of investigations}

The optimal decision-making when drilling wells requires an analysis of objectively existing, identified as a result of studies during the drilling process, qualitative and quantitative relationships of various geological and technological factors affecting the performance of this process, research and identification of the relationships between geological, geophysical, mechanical and technological characteristics of the section. Such regularities make it possible to further study the geological section, evaluate those geological characteristics that have not been previously evaluated, and also improve the accuracy of previously estimated characteristics and thereby ensure the development of a system for calculating the characteristics of the geological section (Джанзаков и др., 2019; Дюсенов, 2008; Efendiyev et al., 2017).

It should be noted that in the practical use of well drilling results, it is required to take into account the presence of noise. In this regard it becomes necessary to study some random processes against the background of others (pulsed interference). One of the most effective methods is the automatic selection method, which was used in (Мирзаджанзаде и др., 1973; Агаев, 1989) to estimate the useful signal in the operating parameters. The program that we used includes noise filtering when processing the d-exponent, and a change in the statistics $\mathrm{L}$ allows one to judge whether the system under consideration is homogeneous, i.e. from the value of $\mathrm{L}$ calculated for the indicator of drilling, it is possible to determine homogeneous intervals (Efendiyev et al., 2019; Эфендиев и др., 2019).

In (Brown et al., 2000; Cuddy and Glover, 2002) according to the measured rock characteristics (hardness is taken in our examples) which can be estimated from core studies, mud logging or well logging, the fuzzy possibility $F\left(x_{f}\right)$ is determined. The process is repeated for another parameter, for example, porosity, $y$. This step allows us to obtain $F\left(y_{f}\right)$, a fuzzy possibility that the measured porosity $y$ belongs to the lithotype $f$. This process is repeated for other features characterizing the given rock, then for each lithotype of the rocks to get $F\left(z_{f}\right)$. At this stage we have five fuzzy probabilities $\left(F\left(x_{f}\right), F\left(y_{f}\right), F\left(z_{f}\right) \ldots ..\right)$ which are based on fuzzy possibilities available for different rock characteristics $(x, y, z \ldots)$. They indicate that lithotype $f$ is most likely. The indicated fuzzy possibilities are then harmoniously averaged (2) to obtain the aggregate fuzzy possibility: 


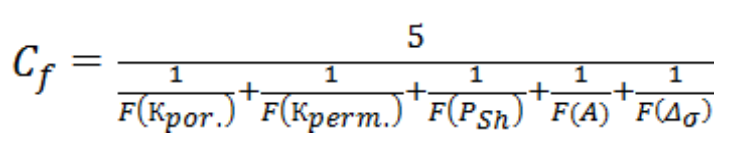

This process is repeated for each lithotype $f$. The lithotype associated with the highest $C_{f}$ is taken as the most probable for a given set of features. This approach was used in our work because it makes the lithological forecast more reliable.

In this article, the noted theoretical prerequisites are considered on the example of forecasting the lithology of the rocks of a section of one of the wells drilled in Azerbaijan by a set of attributes (hardness
$P_{s h}$, abrasiveness $A$, lithology indicator $\Delta_{\sigma}$, porosity $K_{\text {por }}$, permeability $K_{\text {perm }}$ ) obtained as a result of geological, geophysical and technological studies during well drilling. An analysis of the distribution showed (Fig. 1) that for each of the listed attributes, with the exception of permeability, it obeys the normal law (permeability obeys the lognormal law, therefore their logarithms are taken as its values). In all homogeneous intervals, the weighted average values of each of the five parameters are given: porosity, permeability, lithology index, hardness, abrasiveness.

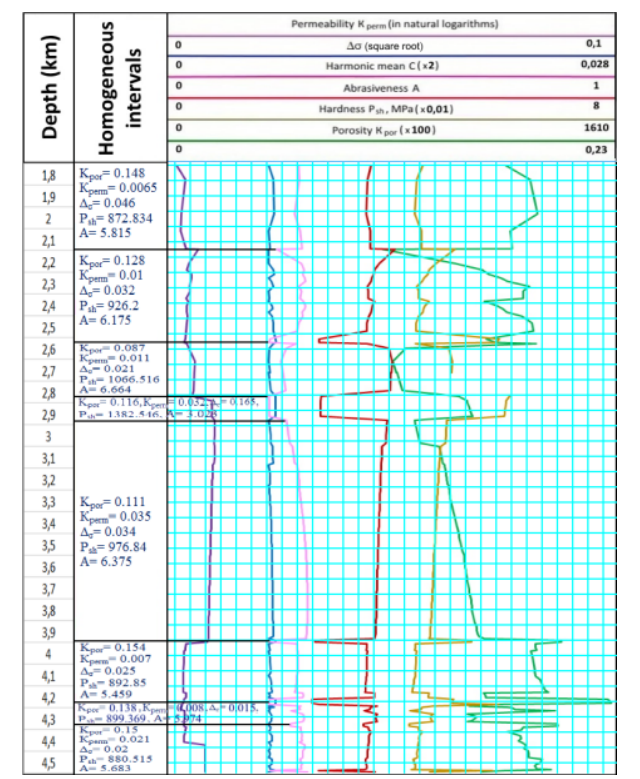

a)

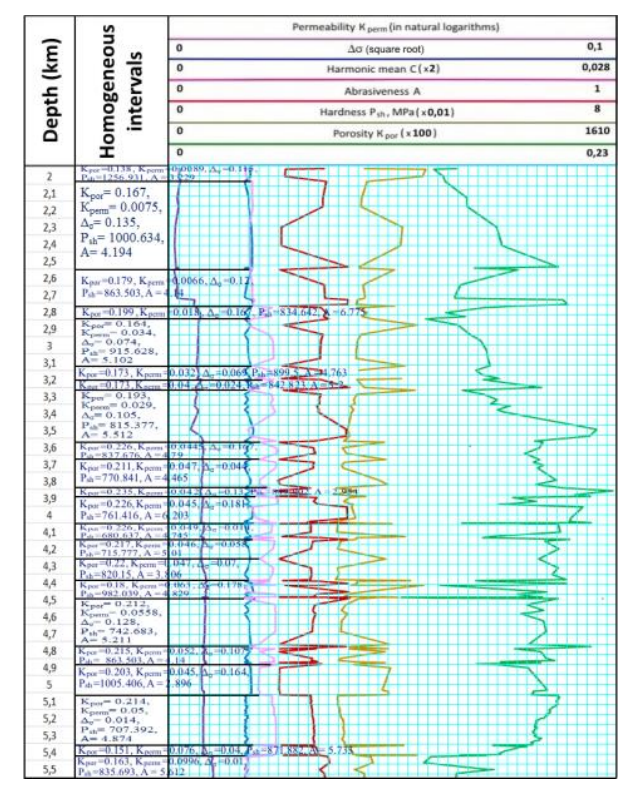

c)

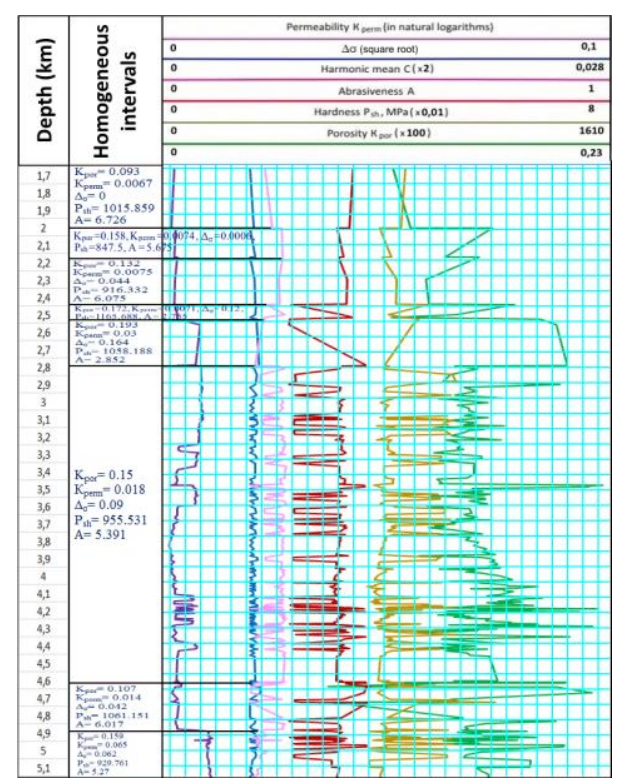

b)

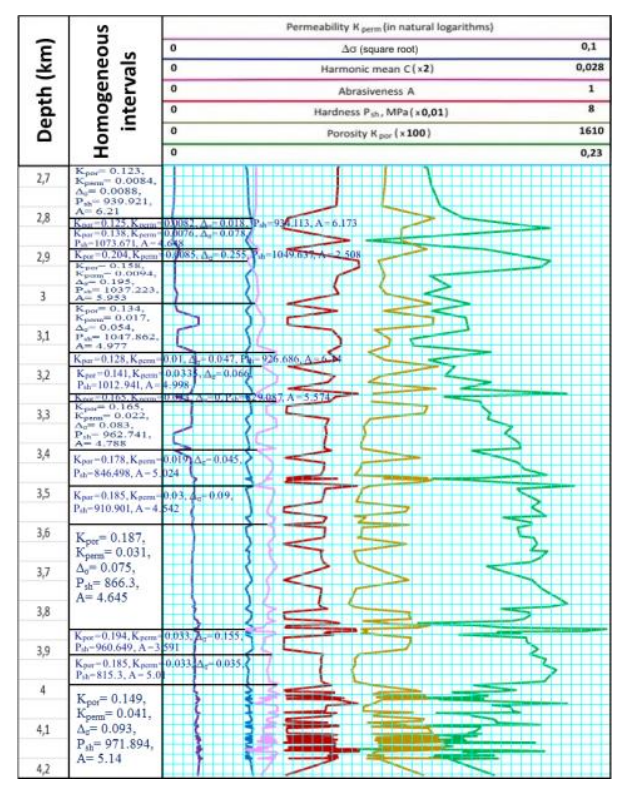

d)

Fig. The results of the analysis of information on drilling wells in the Bahar fields: a) well $8, b$ ) well $40, c$ ) well 9, d) well 72 
The figure clearly traces the boundaries of lithological differences of rocks, identified using the harmonic average of five indicators of rock properties which correlates well with each of the noted characteristics. The results obtained make it possible to enlarge homogeneous packs of rocks, to combine data on the development of bits within these packs, providing a sufficient amount of information about the work of the bits and, as one of the results, to begin to build a model of penetration rate for this rock. Weighted average values of rock characteristics for individual rock differences are shown in the figure. It should be noted that, depending on the problem to be solved, when breaking the section into homogeneous packs, other rock characteristics can also be used. In this case we considered indicators of those rock properties that are necessary for solving well drilling problems.

\section{Conclusions}

As studies have shown, the main purpose of monitoring the drilling process using complex information is the timely warning of emergency situations, improving the performance of bits, and, in general, optimizing the drilling process. During the implementation of any stage carried out at the drilling site, all parameters are recorded and processed in real time. The time of each operation is fixed and

\section{REFERENCES}

Aghayev S.G. A systematic approach to improving the efficiency of well drilling. Abstract of doctoral dissertation, Baku, 1989, 52 p. (in Russian).

Brown D.F., Cuddy S.J., Garmendia-Doval A.B., McCall J.A.W. The prediction of permeability in oil-bearing strata using genetic algorithms. In: Materials of the Third IASTED International Conference Artificial Intelligence and Soft Computing, Banff, Alberta, Canada, July 24-26, 2000, https://www.researchgate.net/publication/220909228_ The_Prediction_of_Permeability_in_Oil-Bearing_Strata_ using_Genetic_Algorithms.

Cuddy S.J., Glover P.W.J. The application of fuzzy logic and genetic algorithms to reservoir characterization and modeling. Soft Computing for Reservoir Characterization and Modeling, No. 1, 2002, pp. 219-241.

Delia S.V., Rakitin M.V. Development tendencies of drilling's geology-technological and geophysical surveys. Drilling and oil, No. 2, 2014, http://naukarus.com/tendentsiirazvitiya-gti-i-gis-bureniya (in Russian).

Dyusenov A.T. Improving the efficiency of well drilling by choosing the optimal combination of types of bits and technological parameters. PhD Thesis, Atyrau, 2008, 23 p. (in Russian).

Dzhanzakov I.I., Piriverdiyev I.A., Gulizadeh K.P. et al. Analysis of the state of decision-making methods and tools for drilling wells using integrated geological and technological information. Equipment and technologies for the oil and gas complex, Vol. 111, No. 3, 2019, pp. 51-59 (in Russian).

Efendiyev G.M., Djafarova N.M., Djevanshir R.D. The optimum decision in cutting-type drilling bits selection with regard to their operating conditions and the vagueness of the task posed. Energy sources, Vol. 13, No. 2, 1991, pp. 243-250. used at the next stage when constructing the corresponding dependencies.

Thus, the development of modern technical means and technologies for information support of the well drilling process and their widespread adoption can improve the quality of the information received and requires its appropriate analysis. The operational information obtained during the drilling process is of great importance, as we have already noted, when drilling wells, especially in poorly studied regions with difficult mining and geological and environmental conditions. At the same time, as can be seen from the figure, it is possible to conduct a comparative analysis of changes in rock properties and rate of penetration, to identify homogeneous intervals for rock properties and for drillability in general, in order to trace the intervals of possible complications, etc.

Depending on the problem to be solved, when separating a geological section into homogeneous packs using the proposed algorithm, other rock characteristics can also be used. In this case in connection with the formulation of the main problem we considered the indicators of those rock properties that are necessary when solving problems of drilling wells, in particular, decision-making when choosing bits and operating parameters of drilling.

\section{ЛИТЕРАТУРА}

Brown D.F., Cuddy S.J., Garmendia-Doval A.B., McCall J.A.W. The prediction of permeability in oil-bearing strata using genetic algorithms. In: Materials of the Third IASTED International Conference Artificial Intelligence and Soft Computing, Banff, Alberta, Canada, July 24-26, 2000, https://www.researchgate.net/publication/220909228_The_ Prediction_of_Permeability_in_Oil-Bearing_Strata_using Genetic_Algorithms.

Cuddy S.J., Glover P.W.J. The application of fuzzy logic and genetic algorithms to reservoir characterization and modeling. Soft Computing for Reservoir Characterization and Modeling, No. 1, 2002, pp. 219-241.

Efendiyev G.M., Djafarova N.M., Djevanshir R.D. The optimum decision in cutting-type drilling bits selection with regard to their operating conditions and the vagueness of the task posed. Energy sources, Vol. 13, No. 2, 1991, pp. 243-250.

Efendiyev G.M., Mammadov P.Z., Piriverdiyev I.A. Modeling and evaluation of rock properties based on integrated logging while drilling with the use of statistical methods and fuzzy logic. 10th International Conference on theory and application of soft computing, computing with words and perceptions - ICSCCW-2019. Advances in intelligent systems and computing book series (AISC), Vol. 1095, 2019, pp. 503-511.

Efendiyev G.M., Mammadov P.Z. Piriverdiyev I.A., Sarbopeyeva M.D. Selection of the best combination of bit types and technological parameters during drilling, taking into account uncertainty. Procedia computer science, Vol. 120, 2017, pp. 67-74.

Taylor T.R., Kittridge M.G., Winefield P.L. et al. Reservoir quality and rock properties modeling results - Jurassic and 
Efendiyev G.M., Kuliyev H.H., Piriverdiyev I.A. et al. Methods and tools to improve the quality of information in decision making in well drilling management. Collection of scientific papers: rock destruction and metalworking tools techniques and technology for their production and use. Kiev, V.N.Bakul Institute for superhard materials, Vol. 22, 2019, pp. 52-62 (in Russian).

Efendiyev G.M., Mammadov P.Z., Piriverdiyev I.A. Modeling and evaluation of rock properties based on integrated logging while drilling with the use of statistical methods and fuzzy logic. 10th International Conference on theory and application of soft computing, computing with words and perceptions - ICSCCW-2019. Advances in intelligent systems and computing book series (AISC), Vol. 1095, 2019, pp. 503-511.

Efendiyev G.M., Mammadov P.Z., Piriverdiyev I.A., Sarbopeyeva M.D. Selection of the best combination of bit types and technological parameters during drilling, taking into account uncertainty. Procedia computer science, Vol. 120, 2017, pp. 67-74.

Mirzadzhanzadeh A.Kh., Aghayev S.G., Alimammadov A.F. et al. Guidance on the application of the mathematical theory of the experiment to the study of rock properties and the process of their destruction. Nedra. Moscow, 1973, $98 \mathrm{p}$. (in Russian).

Rakitin M.V. Problems and prospects of using the GTI and GISdrilling (LWD) based on the experience of drilling production wells on the North Caspian shelf. Drilling and oil, No. 07-08, 2015, https://burneft.ru/archive/issues/2015-07-08/26 (in Russian).

Rodionov D.A. Statistical methods of distinguishing geological objects by a set of features. Nedra. Moscow, 1968, 158 p. (in Russian).

Taylor T.R., Kittridge M.G., Winefield P.L. et al. Reservoir quality and rock properties modeling results - Jurassic and Triassic sandstones: Greater Shearwater Area, UK Central North Sea. Marine and Petroleum Geology, Vol. 65, 2015, pp. 1-21.

Wawrzyniak-Guz K. Rock physics modelling for determination of effective elastic properties of the lower Paleozoic shale formation, North Poland. Acta Geophysica, Vol. 67, 2019, pp. 1967-1989.

Wang Z., Wang R., Li T., Schmitt D.R. Modelling of viscoelastic properties of porous rocks saturated with viscous fluid at seismic frequencies at the Core Scale. Workshop: Rock physics and borehole geophysics, Beijing, 28-30 August 2016, https://library.seg.org/doi/abs/10.1190/RP2016-003.
Triassic sandstones: Greater Shearwater Area, UK Central North Sea. Marine and Petroleum Geology, Vol. 65, 2015, pp. 1-21.

Wawrzyniak-Guz K. Rock physics modelling for determination of effective elastic properties of the lower Paleozoic shale formation, North Poland. Acta Geophysica, Vol. 67, 2019, pp. 1967-1989.

Wang Z., Wang R., Li T., Schmitt D.R. Modelling of viscoelastic properties of porous rocks saturated with viscous fluid at seismic frequencies at the Core Scale. Workshop: Rock physics and borehole geophysics, Beijing, 28-30 August 2016, https://library.seg.org/doi/abs/10.1190/RP2016-003.

Агаев С.Г. Системный подход к повышению эффективности проводки скважины. Автореферат докторской диссертации. Баку, 1989, 52 с.

Делия С.В., Ракитин М.В. Тенденции развития ГТИ и ГИСбурения. Бурение и нефть, No. 2, 2014, http://naukarus.com /tendentsii-razvitiya-gti-i-gis-bureniya.

Джанзаков И.И., Пиривердиев И.А., Гулизаде К.П. и др. Анализ состояния методов и средств принятия решений при бурении скважин по комплексной геологотехнологической информации. Оборудование и технологии для нефтегазового комплекса, Т. 111, No. 3, 2019, c. 51-59.

Дюсенов А.Т. Повышение эффективности бурения скважин путем выбора оптимального сочетания типов долот и технологических параметров. Автореферат кандидатской диссертации. Атырау, 2008, 23 с.

Мирзаджанзаде А.Х., Агаев С.Г., Алимамедов А.Ф. и др. Руководство по применению математической теории эксперимента при исследовании свойств горных пород и процесса их разрушения. Недра. Москва, 1973, 98 с.

Ракитин М.В. Проблемы и перспективы использования ГТИ и ГИС-бурения (LWD) на основе опыта бурения эксплуатационных скважин на шельфе Северного Каспия. Бурение и Нефть, No. 07-08, 2015, https://burneft.ru /archive/issues/2015-07-08/26.

Родионов Д.А. Статистические методы разграничения геологических объектов по комплексу признаков. Недра. Москва, 1968,158 с.

Эфендиев Г.М., Кулиев Г.Г., Пиривердиев И.А. и др. Методы и средства повышения качества информации при принятии решений в управлении процессом бурения скважин. Сборник научных трудов: Породоразрушающий и металлообрабатывающий инструмент - техника и технология его изготовления и применения. Киев, ИСМ им. В.Н.Бакуля НАН Украины, Т. 22, 2019, с. 52-62.

\title{
РАЗДЕЛЕНИЕ ГЕОЛОГИЧЕСКОГО РАЗРЕЗА НА ОДНОРОДНЫЕ ПО БУРИМОСТИ ИНТЕРВАЛЫ НА ОСНОВЕ РЕЗУЛЬТАТОВ МОДЕЛИРОВАНИЯ СВОЙСТВ ГОРНЫХ ПОРОД В ПРОЦЕССЕ БУРЕНИЯ
}

\author{
Пиривердиев И.А. \\ Институт нефти и газа, Наџиональная Академия наук Азербайджана \\ AZ1000, Азербайджан, г. Баку, ул. Ф. Амирова, 9: igorbaku@yandex.ru
}

Резюме. Повышение эффективности и качества бурения скважин во многом зависит от повышения качества получаемой информации. Качество решений, принимаемых в процессе бурения, также существенно зависит от качества информации. Широко используемые в последние годы в мировой практике геолого-технологические исследования в процессе бурения скважин позволяют решить ряд проблем в этом процессе, когда информация о разрезе пробуренной скважины отсутствует или доступна в ограниченном количестве. Применение результатов комплекса геолого-геофизических и технологических исследований позволяет более глубоко изучить данный вопрос и тем самым повысить качество принимаемых решений. Статья посвящена анализу и роли информации, получаемой при бурении, оценке ее качества и методов, способствующих повышению качества информации при принятии решений на различных этапах бурения. Рассмотрены методы обработки данных и анализа информации, показано, как использовать сложную геологическую, геофизическую и технологическую информацию, объяснена целесообразность использования различных методов, известных из математической статистики и теории нечетких множеств. В статье рассмотрены пути повышения качества информации и получения более обширных сведений о пробуренной породе, что позволяет разделить разрез на однородные интервалы. С этой целью применялся из- 
вестный из нечеткой логики подход по нахождению соответствующего критерия для каждого из рассматриваемых показателей, а затем было подсчитано их среднее гармоническое значение. Зависимость между средним гармоническим значением и глубиной служит для определения границ между интервалами. Вышеотмеченный алгоритм был использован для расчетов по четырем скважинам на месторождении Бахар, а результаты были наглядно продемонстрированы с помощью рисунков.

Ключевые слова: комплексная информация, геологический разрез, порода, долота, осложнения, классификация, принятие решений, неопределенность, нечеткая логика

\section{QUYU QAZILMASI ZAMANI SÜXURLARIN MODELLəŞDİRILMəSI NəTİCəLəRINə ӘSASəN GEOLOJI KəSILIŞIN BİRCINS İNTERVALLARA BÖLÜNMOSI}

Piriverdiyev I.A.

Neft va Qaz İstitutu, Azarbaycan Milli Elmlar Akademiyası AZ1000, Bakı şəh., F.Omirov küç., 9: igorbaku@yandex.ru

Xülasə. Quyu qazılmasının effektivliyi və keyfiyyəti əldə edilən informasiyanın keyfiyyətindən asılıdır. Qazma zamanı qəbul edilən qərarların da keyfiyyəti informasiyanın keyfiyyətindən asılıdır. Son zamanlar dünya təcrübəsində geniş istifadə olunan geolojitexnoloji tədqiqatlar qazma zamanı informasiya çatışmazlığı şəraitində bir çox problemlərin həllini həyata keçirməyə imkan yaradır. Bununla əlaqədar təqdim olunan məqalə qazma zamanı kəsiliş haqqında əldə edilən informasiyanın keyfiyyətinin artırılması, qazılan süxurlar haqqında dahageniş məlumatın əldə edilməsi, bunun əsasında kəsilişin bircins intervallara ayrılmasına həsr olunur. İlkin məlumat kimi burada son zamanlar geniş tətbiqini tapmış geoloji-texnoloji tədqiqat sistemlərindən alınmış informasiyadan istifadə olunmuşdur.Bura kəsilişin litologiyası, süxurların məsaməliliyi, bərkliyi və digər xassə göstəriciləri haqqında məlumat daxildir. Đldə edilmiş məlumatın ilkin emalı, onun təhlili adətən ənənəvi statistik üsulların tətbiqi ilə həyata keçirilir. Lakin onu qeyd etmək lazımdır ki, bir çox hallarda qeyd olunmuş üsullar kifayət deyil. Burada mövcud qeyri-müəyyənlik üzündən qərarların qəbulu çətinləşir. Buna görə son zamanlar qeyri-səlis çoxluqlar nəzəriyyəsinə əsaslanan üsullardan geniş istifadə olunur. Qeyd olunmuş məsələ qeyri səlis məntiq əsasında hər baxılan amil üzrə müvafiq meyarın hesablanması, bütün bunların arasında orta harmonik qiymətin təyini vasitəsilə həll olunur. Belə ki, həmin orta harmonik qiymətin dərinlikdən asılılıq əyrisindəki sıçrayışlara uyğun dərinlik bir süxur ilə digər süxurun sərhədi kimi qəbul olunur. Qeyd olunmuş alqoritm üzrə Bahar yatağında qazılmış quyuların timsalında hesablamalar və müvafiq süxur bölgüsü aparılmışdır. Təklif olunmuş yanaşma ilə aparılmış bölgü vasitəsi ilə formalaşmış bircins intervallar üzrə qazma baltalarının iş göstəriciləri təhlil olunaraq onların işinin modelləşdirilməsi və qərarların qəbul edilməsi üzrə mərhələləri həyata keçirmək olar.

Açar sözlər: kompleks informasiya, geoloji kəsiliş, süxur, balta, mürəkkablaşmə, təsnifat, qərarların qəbulu, qeyri müəyyənlik, qeyri salis mantiq 